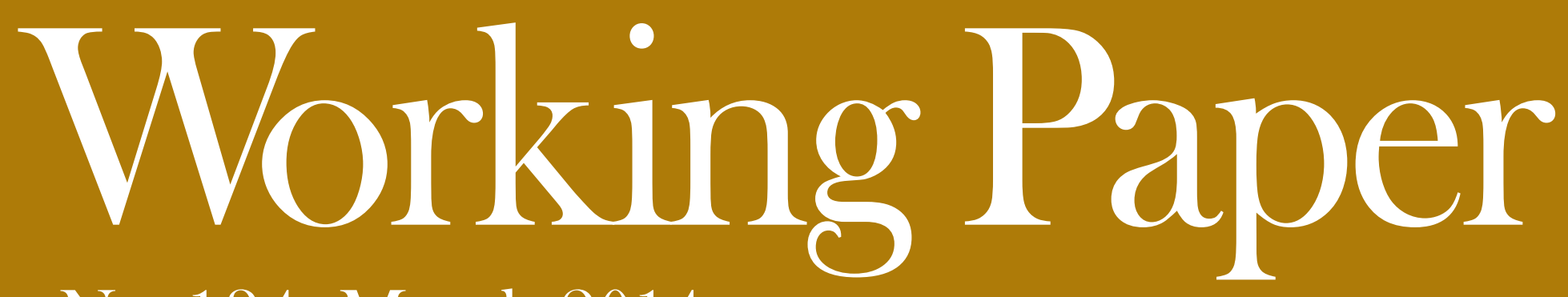

No. 134. March 2014

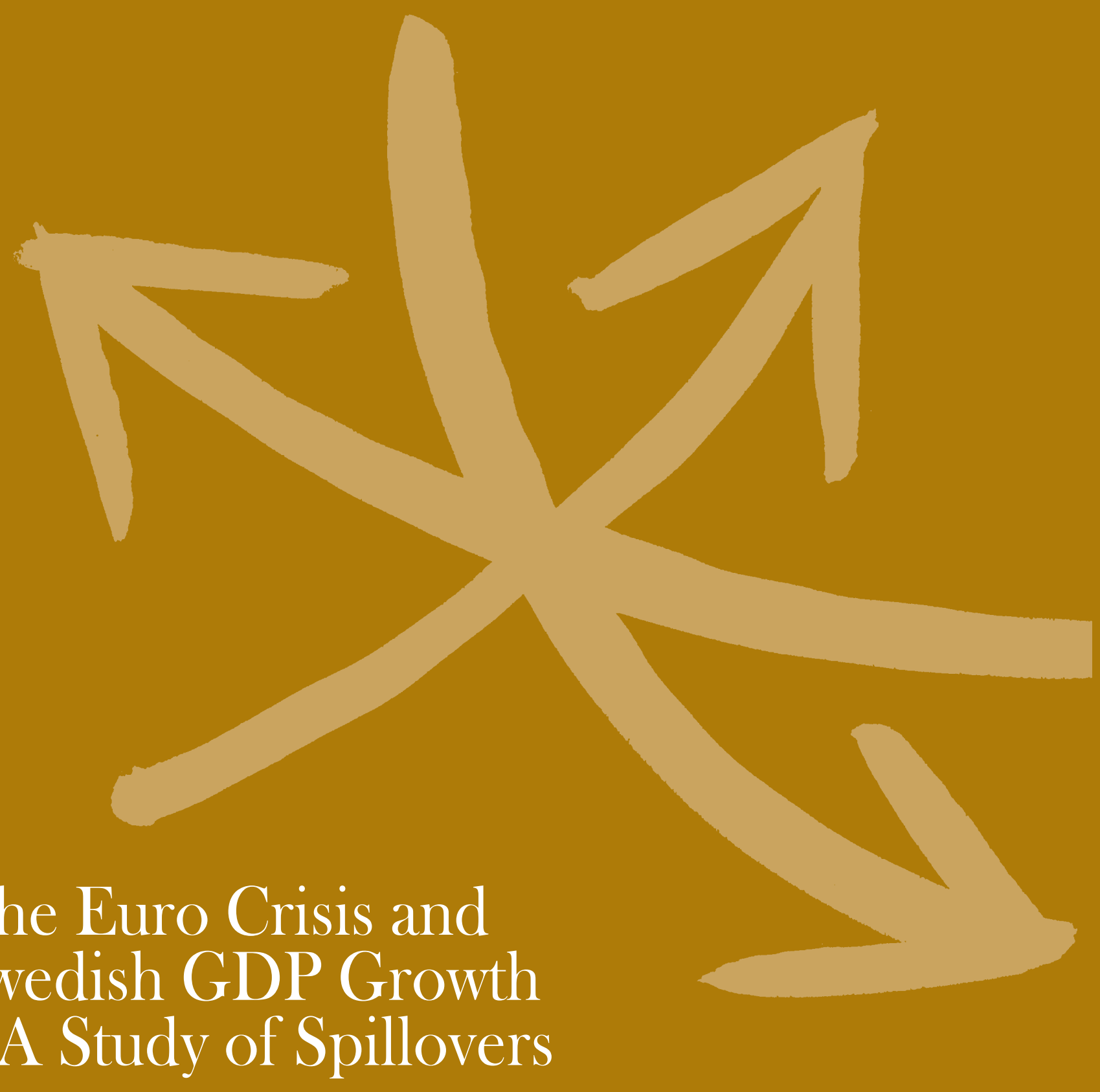

By Pär Österholm and Pär Stockhammar

National Institute of Economic Research

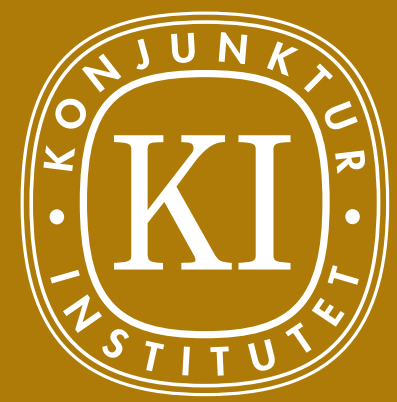





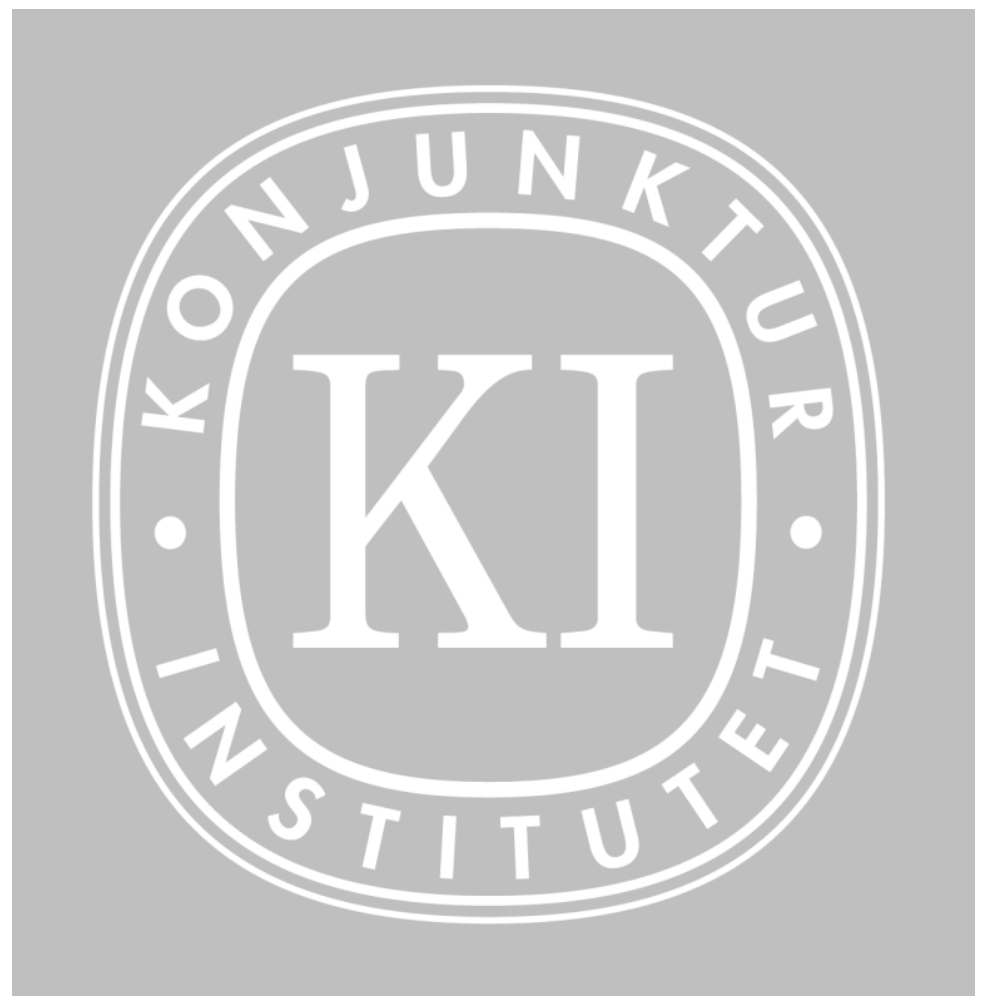

\section{The Euro Crisis and Swedish GDP Growth - A Study of Spillovers}

Pär Österholm* and Pär Stockhammar

March 2014

\footnotetext{
* National Institute of Economic Research, Box 3116, 10362 Stockholm, Sweden e-mail: par.osterholm@konj.se Phone: +46 84535948

\# National Institute of Economic Research, Box 3116, 10362 Stockholm, Sweden

e-mail: par.stockhammar@konj.se Phone: +4684535910
} 
NIER prepares analyses and forecasts of the Swedish and international economy and conducts related research. NIER is a government agency accountable to the Ministry of Finance and is financed largely by Swedish government funds. Like other government agencies, NIER has an independent status and is responsible for the assessments that it publishes.

The Working Paper series consists of publications of research reports and other detailed analyses. The reports may concern macroeconomic issues related to the forecasts of the institute, research in environmental economics, or problems of economic and statistical methods. Some of these reports are published in their final form in this series, whereas others are previews of articles that are subsequently published in international scholarly journals under the heading of Reprints.

Reports in both of these series can be ordered free of charge. Most publications can also be downloaded directly from the NIER website. 


\begin{abstract}
In this paper, a Bayesian VAR model is used to study the effects of euro area shocks on GDP growth in the small open economy of Sweden. A novel feature is that the new policy uncertainty index of Baker et al. (2013) is introduced in the model. The model behaves well in terms of reasonable impulse response functions. The specific effects of the euro crisis are investigated through a historical decomposition which shows that shocks to euro area GDP growth have been a reasonably important factor for Swedish GDP growth, supporting it during 2010 and holding it back thereafter. Generally, shocks to policy uncertainty have held back Swedish GDP growth during the euro crises.
\end{abstract}

JEL classification code: C32, F43

Keywords: Small open economy, Bayesian VAR, Policy uncertainty index 


\section{Sammanfattning}

I denna studie används en bayesiansk VAR-modell för att studera effekterna av störningar i euroområdet på den svenska ekonomin. Ett nytt inslag är att det nyligen utvecklade policyosäkerhetsindexet (Baker et al., 2013) används i modellen. Den skattade modellen har rimliga impulsresponsfunktioner. Eurokrisens specifika effekter undersöks genom en historisk dekomponering. Denna visar att störningar till BNP-tillväxten i euroområdet har varit en relativt viktig faktor för svensk BNP-tillväxt; under 2010 gav den stöd åt svensk BNP-tillväxt och därefter har den verkat återhållande. Generellt sett har störningar till policyosäkerheten hållit tillbaka svensk BNP-tillväxt under eurokrisen. 


\section{Contents}

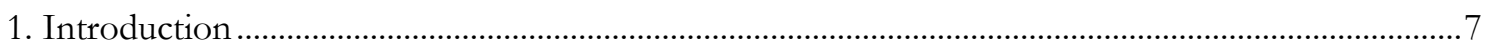

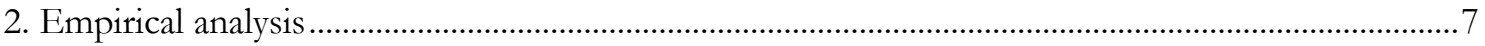

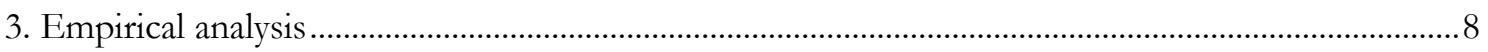

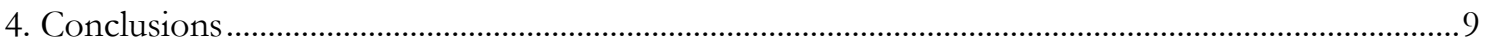

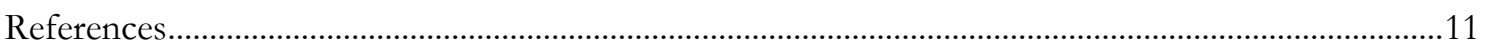

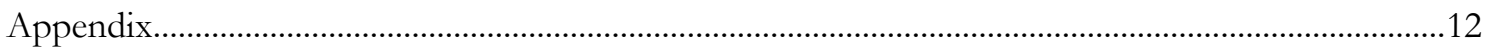





\section{Introduction}

The debt crisis in the euro area which followed upon the global financial crisis in 2008 has, needless to say, caused hardship in several parts of the euro area. The extreme level of the unemployment rate in both Greece and Spain - which in both countries was more than 25 percent in late 2013 - constitutes just one example. However, in an economically and financially integrated world, it is reasonable to suspect that the euro crisis has had effects also outside the euro area, especially for small open economies such as Sweden. Exports are roughly 50 percent of Swedish GDP and more than 35 percent (in 2012) of these were directed to the euro area. Thus, developments in the euro area are of crucial importance to the Swedish economy.

The purpose of this paper is to empirically investigate how the euro area crisis has affected Swedish GDP growth. This is done using a Bayesian VAR (BVAR) model in which we include euro area GDP growth, the new policy uncertainty index of Baker et al. (2013) and the high yield bond spread. Important domestic factors are also controlled for. A historical decomposition of the period 2010Q2 to 2013Q2 using the methodology of Adolfson et al. (2007) is conducted. We accordingly contribute to a fairly large and diverse literature on spillovers between countries and/or regions. ${ }^{1}$

\section{Empirical analysis}

Using data from 1998Q1 to 2013Q2, we estimate the BVAR model

$\mathbf{G}(L)\left(\mathbf{x}_{t}-\boldsymbol{\mu}\right)=\boldsymbol{\eta}_{t}$,

where $\mathbf{G}(L)=\mathbf{I}-\mathbf{G}_{1} L-\ldots-\mathbf{G}_{m} L^{m}$ is a lag polynomial of order $m, \mathbf{x}_{t}$ is an $n \mathbf{x} 1$ vector of stationary variables, $\boldsymbol{\mu}$ is an $n \times 1$ vector describing the steady-state values of the variables in the system and $\boldsymbol{\eta}_{t}$ is an $n \times 1$ vector of $\ddot{i} d$ error terms fulfilling $E\left(\boldsymbol{\eta}_{t}\right)=\mathbf{0}$ and $E\left(\boldsymbol{\eta}_{t} \boldsymbol{\eta}_{t}^{\prime}\right)=\boldsymbol{\Sigma} .{ }^{2}$ The model contains the corresponding variables to those used by Österholm (2010) - where spillovers from the United States to Sweden were investigated - but is here augmented by the policy uncertainty index of Baker et al. (2013). Hence,

$\mathbf{x}_{t}=\left(\begin{array}{lllllll}y_{t}^{e a} & p_{t}^{e a} & H Y_{t}^{e a} & y_{t} & C C_{t} & B C_{t} & F C I_{t}\end{array}\right)^{\prime}$,

\footnotetext{
1 See, for example, Pesaran et al. (2004), Galvão et al. (2007), Österholm and Zettelmeyer (2008), Bagliano and Morana (2010), Bayoumi and Swiston (2009) and Erten (2012).

2 This mean-adjusted specification was developed by Villani (2009).
} 
where $y_{t}^{e a}$ is the percentage change in seasonally adjusted euro area real GDP, $p_{t}^{e a}$ is the European policy uncertainty index and $H Y_{t}^{e a}$ the high yield corporate bond spread in the euro area.,34 The Swedish variables included are the following: $y_{t}$ is the percentage change in real GDP, $C C_{t}$ is a consumer confidence measure based on the Economic Tendency Survey conducted by the National Institute of Economic Research and $B C_{t}$ is a confidence indicator for the manufacturing industry based on the same survey. Finally, $F C I_{t}$ is a financial conditions index for Sweden. Data are shown in Figure A1 in the Appendix.

The priors on the parameters of the model follow those in Villani (2009). The prior on $\boldsymbol{\Sigma}$ is given by $p(\boldsymbol{\Sigma}) \propto|\boldsymbol{\Sigma}|^{-(n+1) / 2}$ and the prior on $\operatorname{vec}(\mathbf{G})$, where $\mathbf{G}=\left(\begin{array}{llll}\mathbf{G}_{1} & \ldots & \mathbf{G}_{m}\end{array}\right)^{\prime}$, is given by $\operatorname{vec}(\mathbf{G}) \sim N_{m n^{2}}\left(\boldsymbol{\theta}_{\mathbf{G}}, \mathbf{\Omega}_{\mathbf{G}}\right)$. Finally, the prior on $\boldsymbol{\mu}$ is given by $\boldsymbol{\mu} \sim N_{n}\left(\boldsymbol{\theta}_{\boldsymbol{\mu}}, \boldsymbol{\Omega}_{\boldsymbol{\mu}}\right) .5$ The hyperparameters of the model follow the literature. ${ }^{6}$ The euro area is modelled as block exogenous with respect to Sweden. This block exogeneity is achieved with a hyperparameter which shrinks the parameters on the Swedish variables in the euro area equations to zero; see Villani and Warne (2003) for details. Finally, the lag length is set to $m=4$.

\section{Empirical analysis}

Impulse response functions are given in Figure A2 in the Appendix and show that the model behaves well in general; 7 they are almost exclusively in line with what we would expect based on economic theory. We accordingly note that shocks to euro area GDP growth have a positive effect on Swedish GDP growth whereas shocks to policy uncertainty or the high yield bond spread have a negative ef-

\footnotetext{
3 The European policy uncertainty index is based on data from France, Italy, Germany, Spain and the United Kingdom. The United Kingdom is obviously not part of the euro area but we argue that the index shold serve well as a proxy for euro area policy uncertainty given the relative weights.

4 The high-yield bond spread is sometimes interpreted as reflecting risk appetite; see, for example, Levy Yeyati and González Rozada (2005) and Österholm and Zettelmeyer (2008). It has also been shown to have predictive power for the real economy; see, for example, Mody and Taylor (2003).

5 The priors for $\boldsymbol{\mu}$ are given in detail in Table A1 in the Appendix. Priors for all variables except the policy uncertainty index follow those in Österholm (2010). For the policy uncertainty index, the prior mean is chosen to be 100 . This is based on the fact that Baker et al. (2013) normalise the index to have a mean of 100 prior to 2011.

${ }^{6}$ See, for example, Doan (1992) and Villani (2009). The overall tightness is set to 0.2 , the cross-variable tightness to 0.5 and we employ a lag decay parameter of 1 .

7 The impulse response functions are based on a Cholesky decomposition of the covariance matrix with the ordering of the variables given by equation (2).
} 
fect. For instance, a one standard deviation shock to the euro area policy uncertainty index has a maximum effect of around minus 0.1 percent on Swedish GDP growth after one quarter.

In order to assess the importance of the euro area crisis for Swedish GDP growth, we conduct a historical decomposition of the period 2010Q2 to 2013Q2.8 This is performed using the approach of Adolfson et al. (2007). The starting point of this is a comparison between the endogenous forecast generated at a particular point in time and the actual outcome; seeing that the discrepancy between the two is due to shocks that hit the system, we can use the shocks that the model have identified to illustrate the causes of the economy's development.

Results from this exercise are shown in Figure A3 in the Appendix where each panel shows the endogenous forecast, the actual growth rate for Swedish GDP and what the growth rate would have been if only the shocks to the variable in question had hit the system. ${ }^{9}$ During 2010Q2 to 2010Q4, actual Swedish GDP growth was higher than the endogenous forecast, implying that some combination of favourable shocks hit the economy during this period. As can be seen from Figure A3, the main contributing factors were euro area growth and Swedish GDP growth itself. Shocks to euro area policy uncertainty and the high yield bond spread marginally held back Swedish GDP growth.

During the period 2011Q1 to 2012Q2 actual growth was sometimes higher than the endogenous forecast and sometimes lower. During this period, shocks to euro area growth typically had a negative effect on Swedish GDP growth. The second half of this period, euro area policy uncertainty shocks also held back Swedish GPD growth in a quantitatively meaningful way. Shocks to the high yield bond spread had a marginally positive effect on Swedish GDP growth during this period.

Finally, during the period 2012Q3 to 2013Q2 Swedish GDP growth was consistently lower than the endogenous forecast. This is mainly due to weaker than expected euro area growth during this period. The high yield bond spread counteracted the effect to some extent 2012Q4 and 2013Q1.

\section{Conclusions}

Small open economies are greatly affected by the economic developments of bigger surrounding economies. In this paper the effects of euro area shocks on Swedish GDP growth are studied, thereby providing an example of analysis of spillovers of shocks to a small open economy. It is shown that euro area shocks have had considerable effects on Swedish GDP growth. The con-

\footnotetext{
8 This choice of the starting point for the euro crisis is obvoiusly arbitrary but by 2010Q2, signs of problems were showing in terms of rising spreads on Greek government debt.

${ }^{9}$ It can first be noted that the domestic control factors have had a very small effect on Swedish GDP growth during the time for the euro crises (as can be seen from the bottom two rows of Figure A3).
} 
clusion is reached using impulse response functions from a Bayesian VAR model estimated on quarterly data from 1998 to 2013 and a historical decomposition made during the time for the euro crises. The new policy uncertainty index of Baker et al. (2013) was also shown to largely have affected Swedish GDP growth negatively during this period. 


\section{References}

Adolfson, M., Andersson, M. K., Lindé, J., Villani, M. and Vredin, A. (2007), "Modern Forecasting Models in Action: Improving Macro Economic Analyses at Central Banks", International Journal of Central Banking 3, 111-44.

Bagliano, F. and Morana, C. (2010), "Business Cycle Comovement in the G-7: Common Shocks or Common Transmission Mechanisms?", Applied Economics 42, 2327-2345.

Baker, S. R., Bloom, N. and Davis, S. J. (2013), "Measuring Economic Policy Uncertainty", Unpublished manuscript, http://www.policyuncertainty.com/.

Bayoumi, T. and Swiston, A. (2009), "Foreign Entanglements: Estimating the Source and Size of Spillovers Across Industrial Countries", IMF Staff Papers 56, 353-383.

Doan, T. A. (1992), RATS Users Manual, Version 4.

Erten, B. (2012), "Macroeconomic Transmission of Eurozone Shocks to Emerging Economies", International Economics 131, 43-70.

Galvão, A. B., Artis, M. and Marcellino, M. (2007), "The Transmission Mechanism in a Changing World”, Journal of Applied Econometrics 22, 39-61.

Levy Yeyati, E. and González Rozada, M. (2005), "Global Factors and Emerging Market Spreads”, IDB Working Paper No. 552, Inter-American Development Bank.

Mody, A. and Taylor, M. P. (2003), "The High-Yield Spread as a Predictor of Real Economic Activity: Evidence of a Financial Accelerator for the United States", IMF Staff Papers 50, 373-402.

Österholm, P. (2010), "The Effect on the Swedish Real Economy of the Financial Crisis", Applied Financial Economics 20, 265-274.

Österholm, P. and Zettelmeyer, J. (2008), "The Effect of External Conditions on Growth in Latin America”, IMF Staff Papers 55, 595-623.

Pesaran M. H., Schuermann T. and Weiner S. M. (2004), "Modeling Regional Interdependencies Using a Global Error-Correcting Macroeconometric Model", Journal of Business and Economic Statistics 22, 129-162.

Villani, M. (2009), "Inference in Vector Autoregressive Models with an Informative Prior on the Steady State", Journal of Applied Econometrics 24, 630-650.

Villani, M. and Warne, A. (2003), "Monetary Policy Analysis in a Small Open Economy Using Bayesian Cointegrated Structural VARs", Working Paper No. 296, European Central Bank. 


\section{Appendix}

Table A1. Steady-state priors for the Bayesian VAR.

$\begin{array}{lc}\text { Variable } & \text { Prior interval } \\ y_{t}^{e a} & (0.50,0.75) \\ p_{t}^{e a} & (95.0,105.0) \\ H Y_{t}^{e a} & (3.0,6.0) \\ y_{t} & (0.50,0.75) \\ C C_{t} & (-5.0,5.0) \\ B C_{t} & (95.0,105.0) \\ F C I_{t} & (95.0,105.0)\end{array}$

Note: Ninety-five percent prior probability intervals for parameters determining the unconditional means. Prior distributions are all assumed to be normal. Variables are defined in equation (2). 
Figure A1. Data.

Euro area GDP grow th

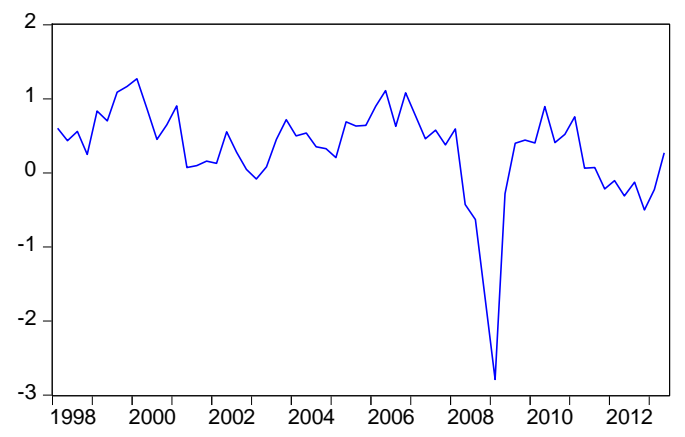

High yield bond spread

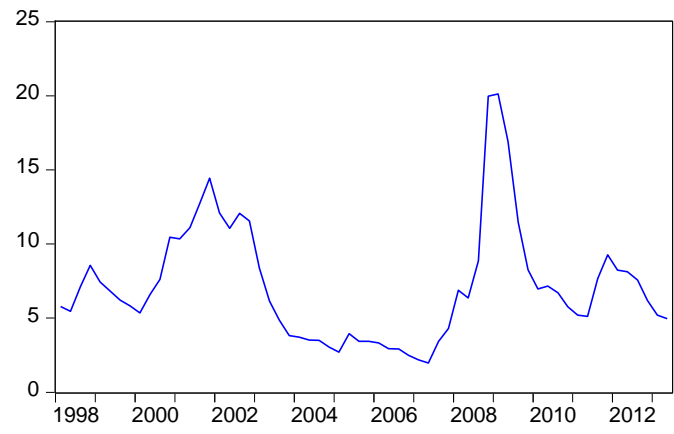

Consumer confidence

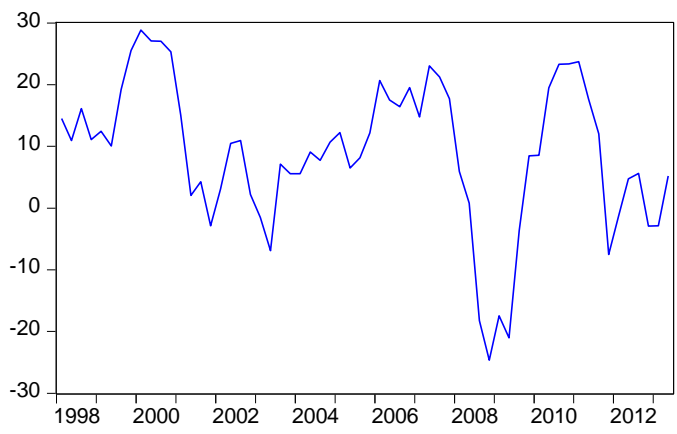

Policy uncertainty index

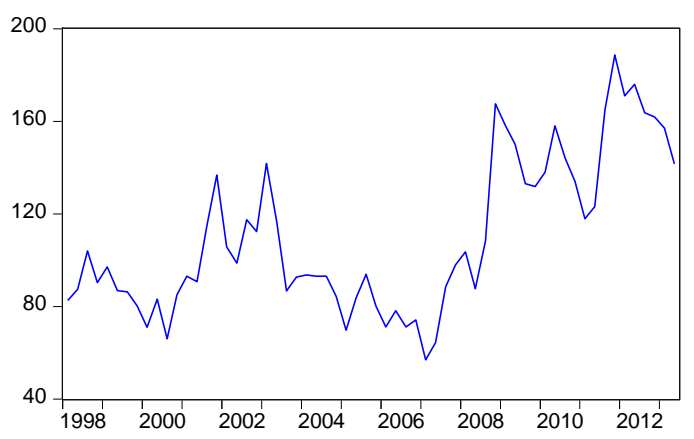

Sw edish GDP grow th

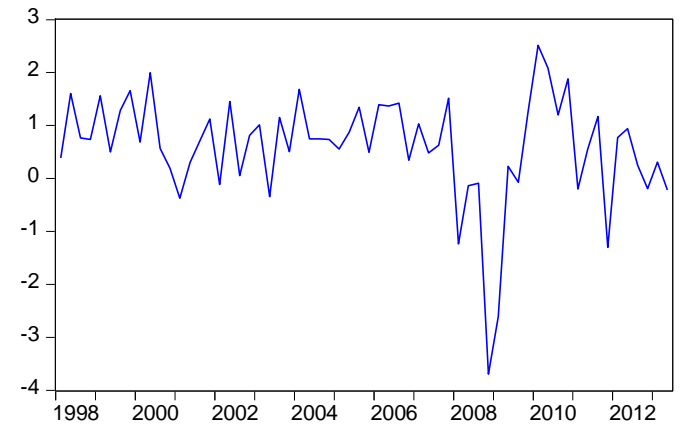

Business confidence

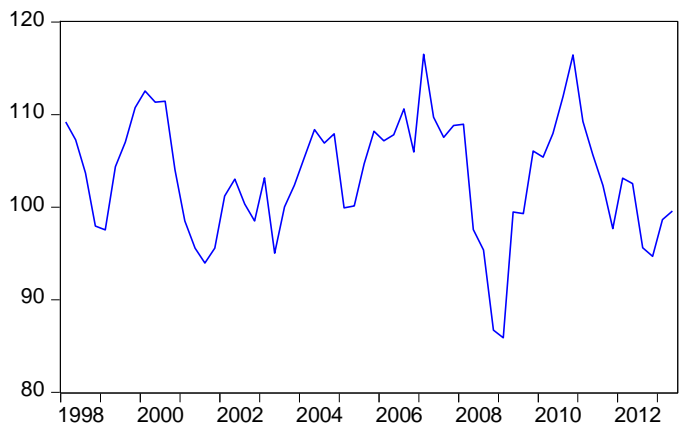

Financial conditions index

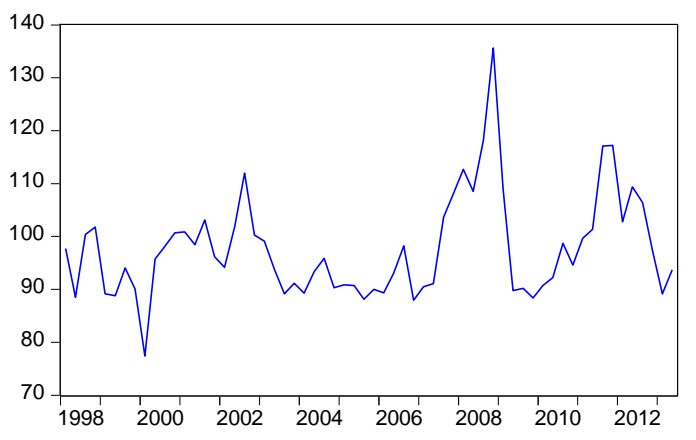

Note: Euro area and Swedish GDP growth are measured in percent. Policy uncertainty, consumer confidence, business confidence and the financial index are all indices. The high yield bond spread is measured in percentage points. 
Figure A2. Impulse response functions from the Bayesian VAR-model.
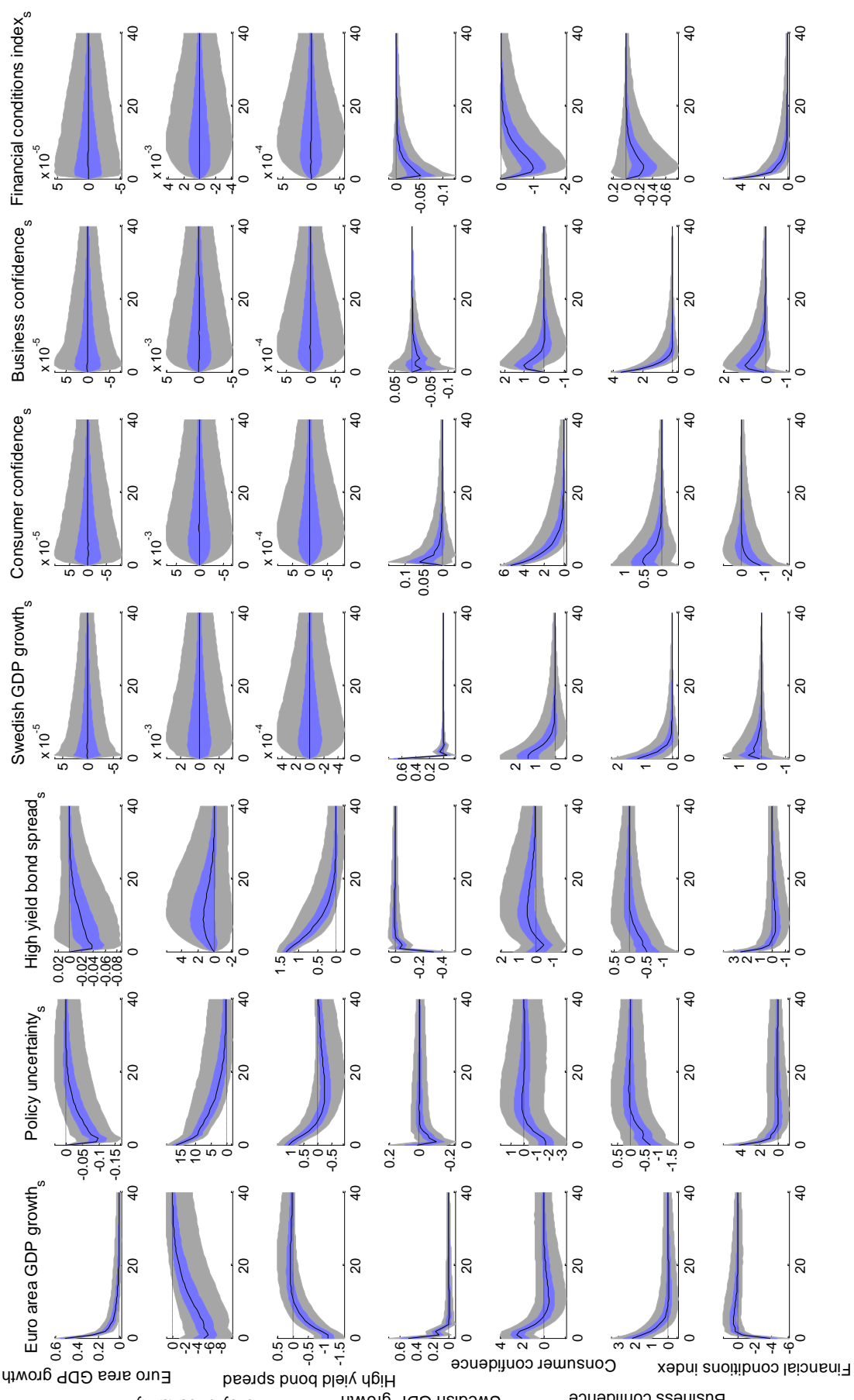

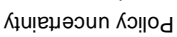

чцмољ6 da९ чs!рәмS

әэиәр!ฺนоo ssəu!sng

Note: Shocks in columns. Black line is the median. Coloured bands are $50 \%$ and $90 \%$ confidence bands. Maximum horizon is 40 quarters. 
Figure A3. Euro area and domestic factors in Swedish GDP growth 2010Q2-2013Q2.
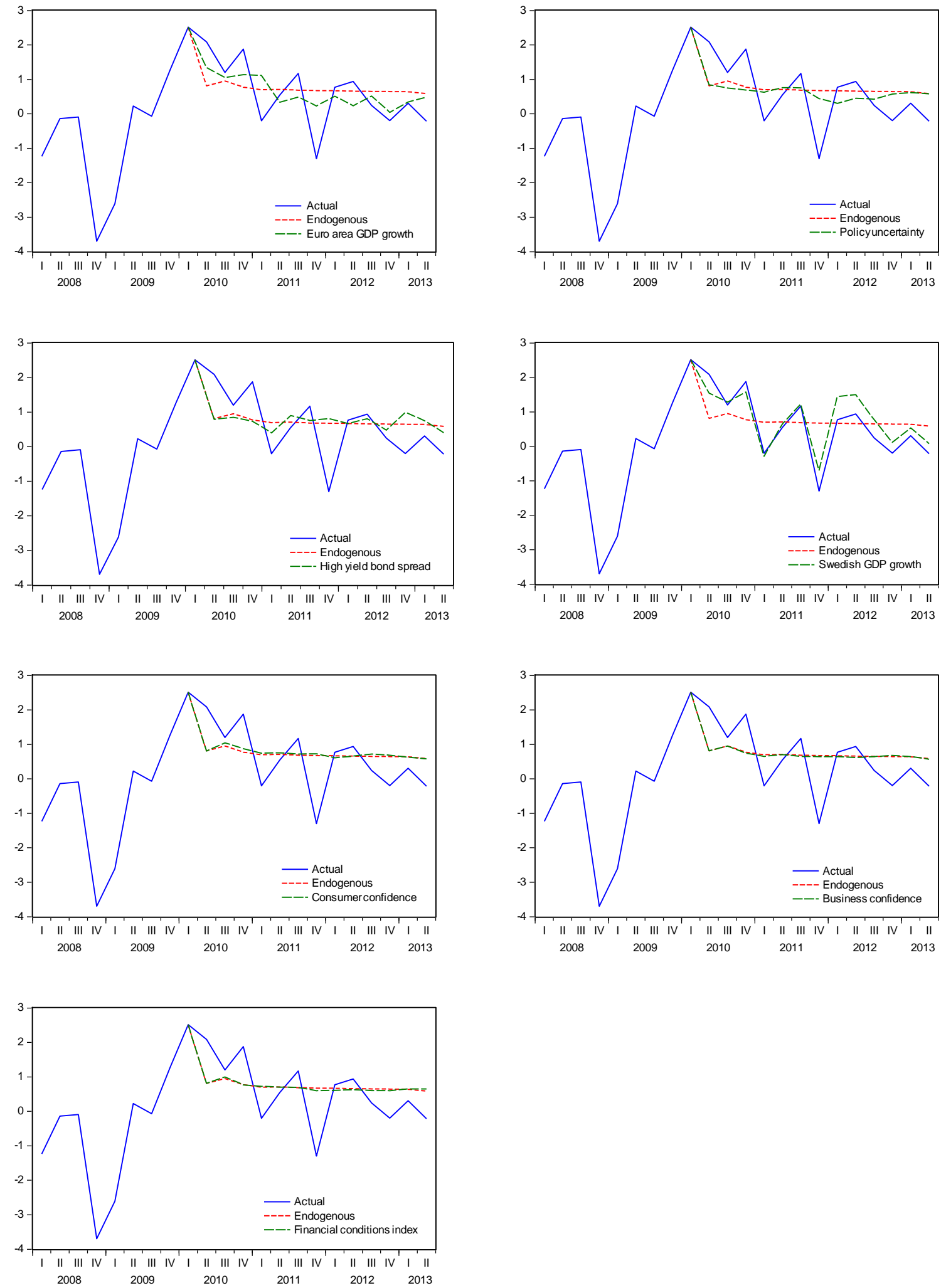

Note: Historical decomposition of Swedish GDP growth using the method of Adolfson et al. (2007). 


\section{Titles in the Working Paper Series}

\begin{tabular}{|c|c|c|c|}
\hline 106 & $\begin{array}{l}\text { Alek Markowski, } \\
\text { Kristian Nilsson, } \\
\text { Marcus Widén }\end{array}$ & $\begin{array}{l}\text { Strukturell utveckling av arbetskostnad och priser i } \\
\text { den svenska ekonomin }\end{array}$ & 2011 \\
\hline 107 & $\begin{array}{l}\text { Forslund, Johanna, } \\
\text { Per Johansson, Eva } \\
\text { Samakovlis and Maria } \\
\text { Vredin Johansson }\end{array}$ & $\begin{array}{l}\text { Can we by time? Evaluation. Evaluation of the } \\
\text { government's directed grant to remediation in Sweden }\end{array}$ & 2009 \\
\hline 108 & $\begin{array}{l}\text { Forslund, Johanna } \\
\text { Eva Samakovlis, Maria } \\
\text { Vredin Johansson and } \\
\text { Lars Barregård }\end{array}$ & $\begin{array}{l}\text { Does Remediation Save Lives? } \\
\text { On the Cost of Cleaning Up } \\
\text { Arsenic-Contaminated } \\
\text { Sites in Sweden }\end{array}$ & 2009 \\
\hline 109 & $\begin{array}{l}\text { Sjöström, Magnus and } \\
\text { Göran Östblom }\end{array}$ & $\begin{array}{l}\text { Future Waste Scenarios for Sweden on the Basis of a } \\
\text { CGE-model }\end{array}$ & 2009 \\
\hline 110 & Österholm, Pär & $\begin{array}{l}\text { The Effect on the Swedish Real Economy of the } \\
\text { Financial Crisis }\end{array}$ & 2009 \\
\hline 111 & Forsfält, Tomas & $\begin{array}{l}\text { KIMOD } 2.0 \text { Documentation of changes in the model } \\
\text { from January } 2007 \text { to January } 2009\end{array}$ & 2009 \\
\hline 112 & Österholm, Pär & $\begin{array}{l}\text { Improving Unemployment Rate Forecasts Using } \\
\text { Survey Data }\end{array}$ & 2009 \\
\hline 113 & Österholm, Pär & $\begin{array}{l}\text { Unemployment and Labour-Force } \\
\text { Participation in Sweden }\end{array}$ & 2009 \\
\hline 114 & $\begin{array}{l}\text { Jonsson, Thomas and } \\
\text { Pär Österholm }\end{array}$ & $\begin{array}{l}\text { The Properties of Survey-Based } \\
\text { Inflation Expectations in Sweden }\end{array}$ & 2009 \\
\hline 115 & $\begin{array}{l}\text { Hjelm, Göran and } \\
\text { Kristian Jönsson }\end{array}$ & $\begin{array}{l}\text { In Search of a Method for Measuring the Output Gap } \\
\text { of the Swedish Economy }\end{array}$ & 2010 \\
\hline 116 & Vartiainen, Juhana & Interpreting Wage Bargaining Norms & 2010 \\
\hline 117 & $\begin{array}{l}\text { Mossfeldt, Marcus and } \\
\text { Pär Österholm }\end{array}$ & $\begin{array}{l}\text { The Persistent Labour-Market Effects of the Financial } \\
\text { Crisis }\end{array}$ & 2010 \\
\hline 118 & $\begin{array}{l}\text { Östblom, Göran, } \\
\text { Maria Ljunggren } \\
\text { Söderman and Magnus } \\
\text { Sjöström }\end{array}$ & $\begin{array}{l}\text { Analysing future solid waste generation - Soft linking } \\
\text { a model of waste management with a CGE-model for } \\
\text { Sweden }\end{array}$ & 2010 \\
\hline 119 & $\begin{array}{l}\text { Broberg, Thomas, } \\
\text { Per-Olov Marklund, } \\
\text { Eva Samakovlisa and } \\
\text { Henrik Hammar }\end{array}$ & $\begin{array}{l}\text { Does environmental leadership pay off for Swed-ish } \\
\text { industry? - Analyzing the effects of environ-mental } \\
\text { investments on efficiency }\end{array}$ & 2010 \\
\hline 120 & $\begin{array}{l}\text { Gustavsson, Magnus } \\
\text { and Pär Österholm }\end{array}$ & $\begin{array}{l}\text { Labor-Force Participation Rates and the } \\
\text { Informational Value of Unemployment Rates: } \\
\text { Evidence from Disaggregated US Data }\end{array}$ & 2010 \\
\hline 121 & $\begin{array}{l}\text { Jonsson, Thomas and } \\
\text { Pär österholm }\end{array}$ & $\begin{array}{l}\text { The Forecasting Properties of Survey-Based Wage- } \\
\text { Growth Expectations }\end{array}$ & 2010 \\
\hline 123 & $\begin{array}{l}\text { Broberg, Thomas, } \\
\text { Tomas Forsfält and } \\
\text { Göran Östblom }\end{array}$ & $\begin{array}{l}\text { The Excess Cost of Supplementary Constraints in } \\
\text { Climate Policy: The Case of Sweden's Energy } \\
\text { Intensity Target }\end{array}$ & 2011 \\
\hline
\end{tabular}




\begin{tabular}{|c|c|c|c|}
\hline 124 & $\begin{array}{l}\text { Patrik Baard, Henrik } \\
\text { Carlsen, Karin } \\
\text { Edvardsson Björnberg } \\
\text { and Maria Vredin } \\
\text { Johansson }\end{array}$ & $\begin{array}{l}\text { Scenarios and Sustainability. A Swedish Case Study of } \\
\text { Adaptation Tools for Local Decision-Makers }\end{array}$ & 2011 \\
\hline 125 & $\begin{array}{l}\text { Hansson, Sven Ove, } \\
\text { Karin Edvardsson } \\
\text { Björnberg and } \\
\text { Maria Vredin } \\
\text { Johansson }\end{array}$ & $\begin{array}{l}\text { Making Climate Policy Efficient } \\
\text { Implementing a Model for Environmental Policy } \\
\text { Efficiency }\end{array}$ & 2011 \\
\hline 126 & $\begin{array}{l}\text { Antipin, Jan-Erik, } \\
\text { Farid Jimmy } \\
\text { Boumediene and Pär } \\
\text { Österholm }\end{array}$ & $\begin{array}{l}\text { Forecasting Inflation Using Constant Gain Least } \\
\text { Squares }\end{array}$ & 2012 \\
\hline 127 & $\begin{array}{l}\text { Meredith Beechey, Pär } \\
\text { Österholm }\end{array}$ & $\begin{array}{l}\text { Policy Interest Rate Expectations in Sweden: A } \\
\text { Forecast Evaluation }\end{array}$ & 2012 \\
\hline 128 & $\begin{array}{l}\text { Meredith Beechey, Pär } \\
\text { Österholm }\end{array}$ & $\begin{array}{l}\text { Central Bank Forecasts of Policy Interest Rates: An } \\
\text { Evaluation of the First Years }\end{array}$ & 2013 \\
\hline 129 & $\begin{array}{l}\text { Jan-Erik Antipin, } \\
\text { Farid Jimmy } \\
\text { Boumediene, Pär } \\
\text { Österholm }\end{array}$ & $\begin{array}{l}\text { On the Usefulness of Constant Gain Least Squares } \\
\text { when Forecasting the Unemployment Rate }\end{array}$ & 2013 \\
\hline 130 & Österholm, Pär & $\begin{array}{l}\text { Survey Data and Short-Term Forecasts of Swedish } \\
\text { GDP Growth }\end{array}$ & 2013 \\
\hline 131 & Österholm, Pär & $\begin{array}{l}\text { Forecasting Business Investment in the Short Term } \\
\text { Using Survey Data }\end{array}$ & 2013 \\
\hline 132 & Fromlet, Pia & Exchange Rates, Wages, and Export Price Dynamics & 2013 \\
\hline 133 & $\begin{array}{l}\text { Anna Krook Riekkola, } \\
\text { Charlotte Berg, Erik } \\
\text { O. Ahlgren and Patrik } \\
\text { Söderholm }\end{array}$ & $\begin{array}{l}\text { Challenges in Soft-Linking: The Case of EMEC and } \\
\text { TIMES-Sweden }\end{array}$ & 2013 \\
\hline 134 & $\begin{array}{l}\text { Österholm, Pär, } \\
\text { Stockhammar, Pär }\end{array}$ & $\begin{array}{l}\text { The Euro Crisis and Swedish GDP Growth } \\
\text { - A Study of Spillovers }\end{array}$ & 2014 \\
\hline
\end{tabular}




\section{National Institute of Economic Research, Kungsgatan 12-14, Box 3116, SE-103 62 Stockholm, Sweden}

Phone: +46845359 00, Fax: +4684535980, ki@konj.se, www.konj.se 